\title{
DIVERSITY OF RODENTS AND TREESHREWS IN DIFFERENT HABITATS IN WESTERN SARAWAK, BORNEO
}

\author{
SIEU ZHIEN TEO ${ }^{1}$, YEE LING CHONG ${ }^{2}$ and ANDREW ALEK TUEN ${ }^{1 *}$ \\ ${ }^{1}$ Institute of Biodiversity and Environmental Conservation, Universiti Malaysia Sarawak, \\ 94300 Kota Samarahan, Sarawak, Malaysia \\ ${ }^{2}$ Department of Science and Environmental Studies, The Education University of Hong Kong, \\ 10 Lo Ping Road, Tai Po, New Territories, Hong Kong \\ EE-mail:aatuen@unimas.my
}

Accepted 12 March 2021, Published online 15 May 2021

A diverse community of 63 rodent species and nine treeshrew species are found in Borneo (Phillipps \& Phillipps, 2016). They play an important role in providing ecosystem services by contributing to pollination, seed dispersal, and germination; and also food for larger carnivores (Shanahan \& Compton, 2000; Morand et al., 2006; Payne \& Francis, 2007; Phillipps \& Phillipps, 2016). Bornean tropical forests have been lost, degraded, and fragmented by anthropogenic activities since the early 1970s (Bryan et al., 2013; Gaveau et al., 2014), consequently created new or alternative habitats for rodents and treeshrews especially resilient, adaptive, or opportunistic species that can thrive in such disturbed areas while forest-dependent species would decline in number or become locally extinct (Traweger et al., 2006; Palmeirim et al., 2020).

This study was conducted to determine the species richness and abundance of rodents and treeshrews in four different habitats (i.e. forest, oil palm plantation, rural villages, and urban area) in the western part of Sarawak, Borneo. The data collected from this study is important and useful in contributing new knowledge on the occupancy of anthropogenically created habitats for rodents and treeshrews and gives an insight into how each rodent and treeshrew species responded to human disturbance in term of their species richness and abundance in each habitat type.

Live-trapping using baited cage traps was conducted in the western part of Sarawak (i.e. Bau District, Samarahan District, Serian District, and Kuching City), comprising of a total of seven forests (primary forest, secondary lowland agro-forest, limestone forest, and peat swamp forest), four oil palm plantations, six rural villages, and six urban areas. The trapping session in each habitat type was

* To whom correspondence should be addressed. stopped once the targeted number of 50 or more small mammals were caught. These four habitat types were selected because they are the main landscape in western Sarawak and have been subjected to different degrees of disturbance from a human. Forest sites were categorized as the least disturbed areas and urban sites as the most disturbed areas. Trapped rodents and treeshrews were anesthetized using chloroform ( $\mathrm{Ng}$ et al., 2017). Their morphometric measurements were taken and photographed to aid in species identification. The method of catching rodents and treeshrews generally followed that of Aplin et al. (2003). Identification of rodents and treeshrews was according to the field guide by Phillipps and Phillipps (2016). The species diversity of trapped rodents and treeshrews was determined based on the Shannon diversity index (H').

A total of 5924 trap nights yielded 239 individuals of rodents and treeshrews, comprising of 14 species, four species of treeshrews (family Tupaiidae), four species of squirrels (family Sciuridae), and six species of rats (family Muridae) (Table 1). The $p$-value obtained from the KruskalWallis test shows the species diversity of rodents and treeshrews was significantly different $(p=0.0058)$ among forests, oil palm plantations, rural villages, and urban areas. Dunn's posthoc test shows the species diversity of these small mammals in forests was different from both rural villages and urban areas $(p<0.05)$. Forest harbored the most number of species (13 species) and the most diverse community $\left(H^{\prime}=1.941\right)$. Although the forest sites in this study are accessible to human, it is still the least disturbed habitat compared to oil palm plantations, rural villages and urban areas. This result was similar to Bernard et al. (2009) and Wells et al. (2014) where the small mammal species richness was found to be higher in the forest than in other anthropogenically 


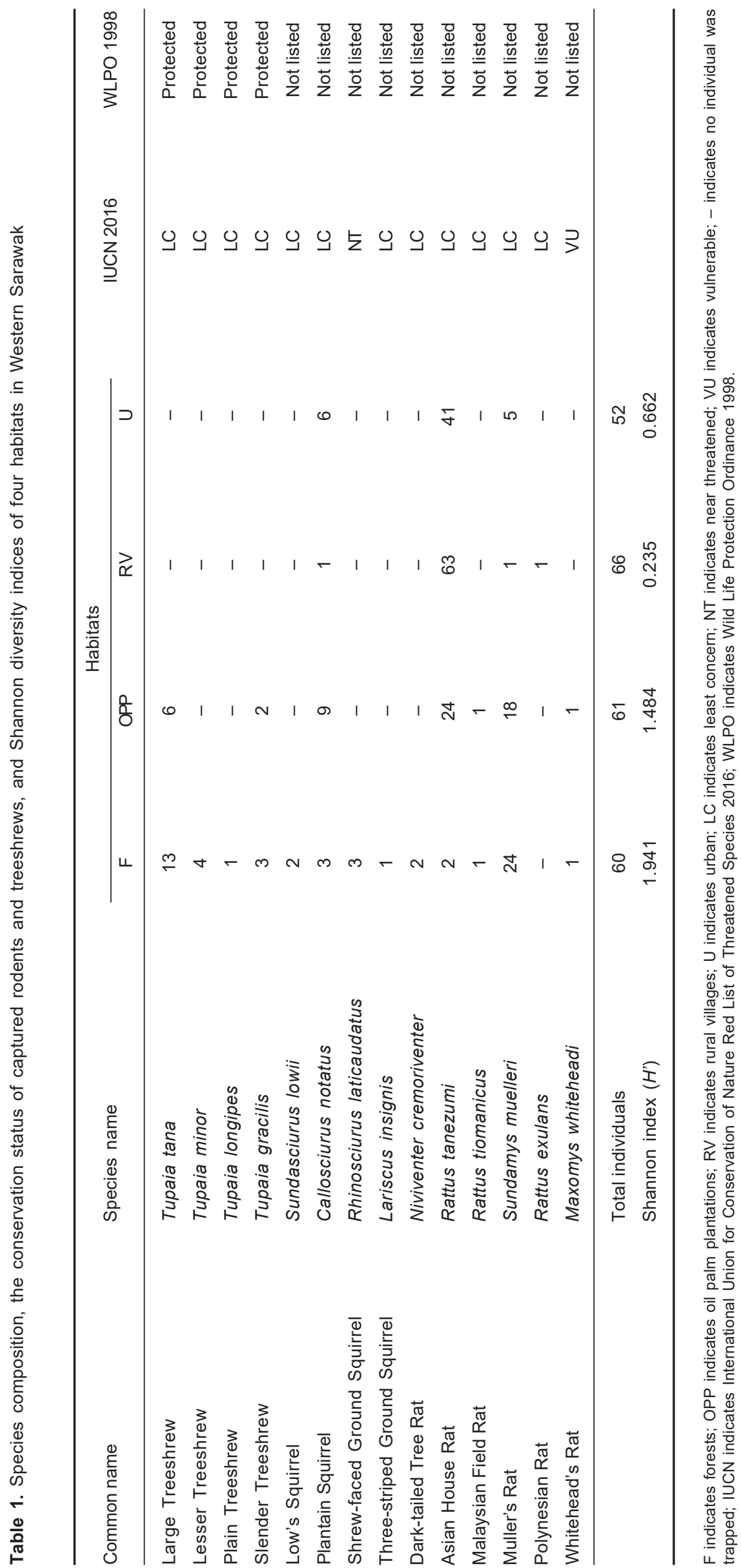


modified habitats. Forest is an important natural habitat for small mammals, particularly treeshrew species in this study. The four treeshrew species (i.e. Tupaia tana, T. minor, T. longipes, and T. gracilis), three squirrels (Sundasciurus lowii, Rhinosciurus laticaudatus, and Lariscus insignis), and three rats (Niviventer cremoriventer, Rattus tiomanicus, and Maxomys whiteheadi) were trapped in the forests were missing from rural villages and urban sites. All treeshrews were listed as protected species under the Wild Life Protection Ordinance (WLPO) 1998.

Oil palm plantation had the next most diverse small mammal community $\left(H^{\prime}=1.484\right.$, seven species $)$. Two treeshrew species were caught in an oil palm smallholding near Kampung Tanah Putih, Samarahan where some of the cage traps were set within 100 meters from the boundary of a forest due to the small land area of the smallholding. Treeshrews from the forest might have entered the oil palm area to forage on palm fruits. Forest patches adjacent to the oil palm plantations are important in maintaining the richness of rodent and treeshrew species in oil palm plantations (Azhar et al., 2014), but this has created some conflicts between wildlife conservationist and planters who do not like the presence of these small mammals in their oil palm plantations.

On the other hand, rural villages had fewer species (four species) and the least diverse small mammal community $\left(H^{\prime}=0.235\right)$; whereas urban areas had the least number of species (three species), but slightly more diverse community than rural villages $\left(H^{\prime}=0.662\right)$. This may due to the higher occurrence probabilities of other rodent species (i.e. Callosciurus notatus and Sundamys muelleri) in an urban area than in the rural villages beside the predominant species, $R$. tanezumi. Although the species richness declined in rural villages and urban areas, both habitats had comparably high trap success $(5.8 \%$ and $5.4 \%$ respectively). This is attributed to the abundance of the synanthropic rat species, Rattus tanezumi. Blasdell et al. (2019) reported that $R$. tanezumi is a dominant species in both suburban and urban areas in western Sarawak. The abundant $R$. tanezumi found in human settlements would have serious public health concerns as this species of commensal rat carries pathogens that have been reported to cause significant morbidity and mortality to humans (Meerburg et al., 2009; Himsworth et al., 2013; Blasdell et al., 2019).

In conclusion, this study showed that when forests are converted into rural villages and urban areas, all four treeshrew and three squirrel species that are associated with forest habitats are not able to adapt to these new habitats and were absent in villages and urban sites. In contrast, synanthropic species such as $R$. tanezumi are well adapted and thrived in human-modified habitats.

\section{ACKNOWLEDGEMENTS}

The authors would like to extend their deepest gratitude to the field assistants and the people at the sampling sites. Special thanks to Sarawak Forest Department for the research permit [Permit no. (287)JHS/NCCD/600-7/2/107 and park permit no. WL141/2018]. This study was funded by a research grant [MPOB/02/2016(IA010200-0706-0003)] and [MPOB/04/2016] awarded to Professor Dr. Andrew Alek Tuen.

\section{REFERENCES}

Aplin, K.P., Brown, P.R., Jacob, J., Krebs, C.J. \& Singleton, G.R. 2003. Field Methods For Rodent Studies In Asia and The Indo-Pacific. Australian Centre for International Agricultural Research, Canberra. 220 pp.

Azhar, B., Lindenmayer, D.B., Wood, J., Fischer, J. \& Zakaria, M. 2014. Ecological impacts of oil palm agriculture on forest mammals in plantation estates and smallholdings. Biodiversity and Conservation, 23(5): 1175-1191.

Bernard, H., Fjeldså, J. \& Mohamed, M. 2009. A case study on the effects of disturbance and conversion of tropical lowland rain forest on the non-volant small mammals in north Borneo: Management implications. Mammal Study, 34(2): 85-96.

Blasdell, K.R., Morand, S., Perera, D. \& Firth, C. 2019. Association of rodent-borne Leptospira spp. with urban environments in Malaysian Borneo. Plos Neglected Tropical Diseases, 13(2): e0007141.

Bryan, J.E., Shearman, P.L., Asner, G.P., Knapp, D.E., Aoro, G. \& Lokes, B. 2013. Extreme differences in forest degradation in Borneo: comparing practices in Sarawak, Sabah, and Brunei. PloS One, 8(7): e69679.

Gaveau, D.L., Sloan, S., Molidena, E., Yaen, H., Sheil, D., Abram, N.K., Ancrenaz, M., Nasi, R., Quinones, M., Wielaard, N. \& Meijaard, E. 2014. Four decades of forest persistence, clearance and logging on Borneo. PloS One, 9(7): e101654.

Himsworth, C.G., Parsons, K.L., Jardine, C. \& Patrick, D.M. 2013. Rats, cities, people, and pathogens: a systematic review and narrative synthesis of literature regarding the ecology of rat-associated zoonoses in urban centers. Vector-Borne and Zoonotic Diseases, 13(6): 349-359.

Meerburg, B.G., Singleton, G.R. \& Kijlstra, A. 2009. Rodent-borne diseases and their risks for public health. Critical Reviews in Microbiology, 35(3): 221-270. 
Morand, S., Kransnov, B.R., Poulin, R. \& Degen, A.A. 2006. Micromammals and macroparasites: Who is who and how do they interact? In: Micromammals and Macroparasites. S. Morand, B.R. Krasnov and R. Poulin (Eds.). Springer, Tokyo. pp. 3-9.

Ng, Y.L., Hamdan, N.E.S., Tuen, A.A., Mohd-Azlan, J. \& Chong, Y.L. 2017. Co-infections of ectoparasite species in synanthropic rodents of western Sarawak, Malaysian Borneo. Tropical Biomedicine, 34(3): 723-731.

Palmeirim, A.F., Santos-Filho, M. \& Peres, C.A. 2020. Marked decline in forest-dependent small mammals following habitat loss and fragmentation in an Amazonian deforestation frontier. PloS One, 15(3): e0230209.

Payne, J. \& Francis, C.M. 2007. A Field Guide to the Mammals of Borneo. The Sabah Society, Kota Kinabalu. 332 pp.
Phillipps, Q. \& Phillipps, K. 2016. Phillipps’ Field Guide To The Mammals of Borneo Sabah, Sarawak, Brunei, and Kalimantan. Natural History Publications (Borneo), Kota Kinabalu. $400 \mathrm{pp}$.

Shanahan, M. \& Compton, S.G. 2000. Fig-eating by Bornean tree shrews (Tupaia spp.): evidence for a role as seed dispersers. Biotropica, 32(4a): 759-764.

Traweger, D., Travnitzky, R., Moser, C., Walzer, C. \& Bernatzky, G. 2006. Habitat preferences and distribution of the brown rat (Rattus norvegicus Berk.) in the city of Salzburg (Austria): implications for an urban rat management. Journal of Pest Science, 79(3): 113-125.

Wells, K., Lakim, M.B. \& O’Hara, R.B. 2014. Shifts from native to invasive small mammals across gradients from tropical forest to urban habitat in Borneo. Biodiversity and Conservation, 23(9): 2289-2303. 